\title{
East European Jewish Immigrants Between Two Worlds. A Preface ${ }^{\star}$
}

Joseph Roth turns time and again in his work to the subject of East European Jewish identity. "Eastern Jews have no home anywhere, but their graves may be found in every cemetery," he writes in connection with the emigration of Jews from Eastern Europe. ${ }^{1}$ The first emigrations from the East European settlements began with the massacres of Jews during the Cossack and peasant uprising in Ukraine in 1648 . They intensified after a number of famines and epidemics in the Russian Empire towards the end of the 1860s, reaching their peak in the "great migration" following anti-Jewish riots in the 1870s and after the mass pogroms that followed the assassination of Tsar Alexander II in 1881. The reinstatement of discriminatory legislation destroyed any hope of equality before the law in the foreseeable future, and the increasing impoverishment of ever larger sections of the Jewish population throughout Eastern Europe led to despair. Millions of Jews moved west, mostly to the USA.

A small number of them also came to Switzerland. Most were just "passing through" (Passanten) - transit travelers who sometimes, however, stayed longer, and occasionally even settled permanently. Yet in addition to these, there were Jews who were living in Switzerland only temporarily, with no intention of immigrating on a permanent basis. Jewish students chose to study in Switzerland because conditions were better here than in their home countries. From the second half of the nineteenth century until the 1917 Russian Revolution there were also a number of Jewish politicians in Switzerland; these were generally members of revolutionary socialist organizations and parties that were forbidden in the countries of Eastern Europe. They hoped that neutral Switzerland would provide an environment in which they could consolidate their ranks and use their networks to influence events in Eastern Europe. It was a similar situation with writers and artists, who moved to Switzerland to escape censorship and a lack of job opportunities. Many of these people planned to return to their respective countries as soon as circumstances allowed. They had no intention of abandoning their homes in Eastern Europe; on the contrary, they wanted to help to improve conditions there. In particular, the General Jewish Labor Bund in Lithuania, Poland and Russia, or the Bund for short, whose activities in Switzerland were very important, espoused the concept of doikayt - the right to belong to a community in the territory where the Jews had been born and raised.

* Translated by Joy Titheridge

1 Roth, Joseph. The Wandering Jews, trans. Michael Hofmann. New York: W. W. Norton \& Company, 2001, 11. 
Most of the immigrants came with an almost mythical image of Switzerland as a traditional haven for refugees characterized by freedom and the rule of law, peace, and the beauty of the landscape. In many respects conditions were indeed favorable. However, they did not always receive a friendly welcome. As in many Central and Western European countries, the legal equality granted Jews in Switzerland in 1866/1874 had not lessened enmity towards them, but in fact actually heightened it because of the fear of competition. Rapid economic and social change further increased the sense of threat. Many Swiss supported efforts to have the rights of the Jews scaled back again. These efforts culminated in the disputes surrounding a ban on shechita that was included in the Swiss Federal Constitution following the referendum on August 20,1893. While hostility was sometimes very vocal and open, there was also a quieter "drawing-room anti-Semitism" that was expressed in little snide and disparaging comments and reflected an entrenched attitude that was part of the "cultural code." In this perception the Jews were "strangers" who did not "belong."

Then came the Ostjuden. Although they were few in number - in 1910, for instance, there were around 650 Jews from the Russian Empire and Galicia living in Basel - their external appearance and religious practice often attracted attention, and warnings were sounded that Switzerland was being "overrun by foreigners.” It soon became clear that this essentially referred to all Jews. Many native Swiss Jews saw this danger. Some of them therefore responded negatively to the Jews from Eastern Europe, fearing that they would undermine the level of - highly unstable - integration that was gradually being achieved. It was only later that they realized that the objective of the opposition to Jews was not rejection of the East European Jews, but of Jews per se. In addition to anti-Jewish campaigns and discrimination, anti-Semitism fueled by the fear of "foreign infiltration" ultimately led to a Swiss refugee policy that was to cost the lives of thousands of Jews who were expelled or refused entry at the border during the "Third Reich.” A specifically Swiss anti-Semitism emerged that claimed it was seeking to prevent anti-Semitism by not allowing Jews into the country in the first place. ${ }^{2}$

In this context, the Ostjude proved to be a stereotyped image of the other, a target that could ultimately be used to attack all Jews. At the same time, however, many of the immigrants also defined themselves as Ostjuden. They generally

2 Cf. Haumann, Heiko. Wir waren alle ein klein wenig antisemitisch. Ein Versuch über historische Massstäbe zur Beurteilung von Judengegnerschaft an den Beispielen Karl von Rotteck und Jacob Burckhardt. Schweizerische Zeitschrift für Geschichte 55 (2005): 196-214 (reprinted in Haumann, Heiko. Schicksale. Menschen in der Geschichte. Ein Lesebuch, 343-364. Cologne, Weimar, Vienna: Böhlau, 2012). On the situation in Basel, see Kury, Patrick. Jüdische Lebenswelten in einer Zeit raschen Wandels. Ostjuden, Zionistenkongresse, Überfremdungsängste um 1900. In Acht Jahrhunderte Juden in Basel. Zweihundert Jahre Israelitische Gemeinde Basel, Heiko Haumann (ed.), 140-160. Basel: Schwabe, 2005. 
described themselves as Polish, Lithuanian, or Galician Jews, depending on the region they came from, and in larger immigrant cities like New York they formed landsmanshaftn (hometown associations) accordingly. Nevertheless, the umbrella term Ostjude had emerged over the course of the nineteenth century. They assertively underscored the difference between themselves and the insipid, assimilated West European Jews, staked their claim to a homeland and the use of the Yiddish language in its respective regional form, and proudly pointed to their rich culture, their unique humor, their tradition of self-government. ${ }^{3}$ There are of course distinctions to be made here. It was possible to have given up Yiddish yet still identify as East European Jewish. And even those who had broken away from the Jewish community, perhaps becoming socialist revolutionaries, often remained conditioned by their former East European Jewish milieu, for instance with regard to a certain form of argumentation. The distinction applies equally to the "Ostjüdin." Jewish women in Eastern Europe were traditionally confined to strict gender roles. The radical social transformation that took place in the nineteenth century meant that these roles began to shift, and more and more women broke with tradition. ${ }^{4}$ Among the migrant women in Switzerland were devout Jews who retained their traditional role, as well as women - more frequently in the public eye - who had departed from the traditional path to become students and revolutionaries.

Many of the Jews from Eastern Europe who lived either temporarily or permanently in Switzerland were caught between two worlds: the one from which they came and which shaped them in many ways, and the one in which they now lived. The various influences that came together in this "in-between world" had to be processed. ${ }^{5}$ This ultimately also played an important role in the transfer of culture and knowledge from East to West and vice versa. All of these brief remarks indicate that an exploration of the lives of Jewish immigrants from Eastern Europe in Switzerland requires approaches that are intercultural and hence also interdisciplin-

3 A history of the term Ostjude - and all its ambivalence - has yet to be written. A useful model could be: Berg, Nicolas. Luftmenschen. Zur Geschichte einer Metapher. Göttingen: Vandenhoeck \& Ruprecht, 2008.

4 Cf. Haumann, Heiko (ed.). Luftmenschen und rebellische Töchter. Zum Wandel ostjüdischer Lebenswelten im 19. Jahrhundert. Cologne, Weimar, Vienna: Böhlau, 2003.

5 Cf. Werberger, Annette. Grenzgänge, Zwischenwelten, Dritte - Der jüdische Schriftsteller und Ethnograph S. Anskij. Transversal 5/1 (2004): 62-79; Richers, Julia. Zeiten des Umbruchs und der Liminalität. Lebenswelten Budapester Juden im Vormärz. In Konzeptionen des Jüdischen: Kollektive Entwürfe im Wandel, Petra Ernst, Gerald Lamprecht (eds.), 106-131. Innsbruck: Studienverlag, 2009; on the "marginal man:" Haber, Peter. Zwischen jüdischer Tradition und Wissenschaft. Der ungarische Orientalist Ignác Goldziher (1850-1921), 230-235. Cologne, Weimar, Vienna: Böhlau, 2006; on the concept of "contact zones:" Binnenkade, Alexandra. KontaktZonen. Jüdisch-christlicher Alltag in Lengnau. Cologne, Weimar, Vienna: Böhlau, 2009, 23-26. 
ary. This is what prompted Tamar Lewinsky and Sandrine Mayoraz to organize an international research workshop on "East European Jews in Switzerland.” It was held in Basel from March 28-30, 2012. Powerful presentations and lively discussions made it evident that the chosen approach was eminently appropriate. It became clear that research in the field has provided rich findings since the first pioneering studies in the 1990s, which broke new ground with regard to both content and methodology. ${ }^{6}$ A much clearer picture emerged of the heterogeneity of the immigrant Jews in terms of their background, attitudes and behavior, and their "world of life" (Lebenswelten).

Questions were also raised for future research. Many migrants in Switzerland reflected on their past in Eastern Europe, in the shtetl or elsewhere, while at the same time becoming acquainted with a new way of life here. How did this impact on their lives and activities? How did it make itself felt when they returned to Eastern Europe? How did the image that Jews had of Switzerland change? And also: How did the image that Swiss people had of "the Jews" compare, say, to their image of "the Russians," and how did these images change? How did the different migrant groups communicate with each other - not only the Jewish groups among themselves, but also with the other East European groups? Did national conflicts, for instance between Poles and Russians, affect the East European Jews in Switzerland? How did peoples' sense of identity, as East European Jews or otherwise, change? Can the immigrant groups be broken down into further categories? Can we map a cultural topography of East European Jewish migration in Switzerland? ${ }^{7}$ What distinguished the Swiss places of residence from those in other countries? ${ }^{8}$ Can further sources be identified? The presentations generally concentrated on the second half of the nineteenth century and the years leading up to the First World War. How did migration processes change after this time?

By highlighting numerous individual aspects, the conference cast a fascinating light on the diverse world of East European Jews in Switzerland. The majority of the talks are now presented here to the public in an elaborated form. Tamar Lewinsky and Sandrine Mayoraz are also to be congratulated for this initiative. This important book represents a milestone in research on the migration of Eastern European Jews.

Heiko Haumann

$6 \mathrm{Cf}$. the literature review in the introduction by the two editors.

7 Cf. Richers, Julia. Jüdisches Budapest. Kulturelle Topographien einer Stadtgemeinde im 19. Jahrhundert. Cologne, Weimar, Vienna: Böhlau, 2009.

8 Cf. the recent study by Saß, Anne-Christin. Berliner Luftmenschen. Osteuropäisch-jüdische Migranten in der Weimarer Republik. Göttingen: Wallstein, 2012. 